DOI https://doi.org/10.36059/978-966-397-225-1-10

\title{
LANGUAGE AS A NATIONAL IDENTITY BUILDING TOOL
}

\section{Biletska Oksana}

\section{INTRODUCTION}

Language is an integral part of identity, through which a person associates himself with society, space and civilization.

In the modern world conditions, the interaction of languages and cultures has many facets and ways of its manifestation. Largely, the relevance of this issue is caused by modern social and political trends, as the phenomenon, usually called globalization (though this process does not really include the whole world, i.e. is not global), really affects a large number of countries. Today, it results in the various forms of the languages coexistence to have become a norm for many countries and regions. This situation is intertwined with social, political, and cultural trends, for example, with increased level of migration or with the long-established bilingualism/multilingualism within a country or a region.

Many researchers argue that the interconnection of language and culture is the basis of the fundamental principles of being. Definitely, without this close interaction between culture and language, they are both condemned to fast extinction. The intertwining of globalization and anti-globalization processes creates obstacles to the survival of both the national culture and the national language. In our daily life, basically, we do not pay attention to what language we speak, but this is crucial. The language is a marker of cultural affiliation that shapes our identity.

The current globalized world faces a number of challenges. The very problem of national identity is of a particular acuity, as it is the closely relates the processes of self-awareness and the modern individual's ideological orientations. Particular attention draws the issue of the language importance as an important means of the individual's self-determination as well as the national identity building tool in the context of post-totalitarian society transformations.

That is why the study of the language in all its interdependence with culture as a national identity building tool is a matter of urgency.

\section{Language - Human: the Genesis of Cultural Studies}

One of the main problems of cultural and linguistic research can be attributed to the specifics of the national language, its role in the culture's 
genesis, the phenomenon of dialogue between cultures. As there are actual questions concerning the language's nature, its functions in society and culture, the language is an object of study in various disciplines: cultural studies, philosophy, psychology, logics, semiotics, language and cultural studies, etc. People quite early discovered that language proficiency (speech) is one of the most important differences between humans and animals, and the ability to speak is closely related with the ability to think.

Language is a paradoxical combination of simplicity and complexity, clarity and mystery. This phenomenon, keeping many secrets, still has not been solved to the end. A philosophical understanding of language emphasizes its primary nature, because language not only reflects, but also creates the reality in which a person lives ${ }^{1}$. Reality is updated and fixed in the language. Being verbally recorded, the fact of the historical and intellectual mankind's development is materially embodied and can be passed on to future generations. Language helps humanity develop further, thereby preventing a person from remaining a savage among the most elegant works of art $^{2}$.

From the point of view of linguistics, language is the medium of a person's existence he constantly interacts with, it is an endless and undifferentiated stream of linguistic actions and the associated mental efforts, ideas, memories, experiences that accompany us everywhere as an integral aspect of our everyday existence ${ }^{3}$.

The history of each language reflects the history and culture of the people speaking this language. Studying ancient roots and cultural monuments, we learn which objects, phenomena, and actions were the most important for the people during the language formation at one or another stage of the human development. The lexical fund of the language shows what really surrounds a person and constitutes the subject of his thoughts and concerns, as well as the level of the cultural development; while the language syntactic system tells us how thinking is carried out. Language not only reflects reality, but also interprets it, creating a special reality in which a person lives. Since culture is inseparable from the worldview fixed in the

1 Maslova V. A. (2001). Lingvokul'turologiya [Linguoculturology]. Moscow: Akademiya, p. 26. p. 64.

${ }^{2}$ Potebnya A. A. (1999). Mysl' i yazyk [Thought and language]. Moscow: Labirint,

${ }^{3}$ Katermina V. V. (2014). Rol' cheloveka v yazyke i kul'ture [Human role in language and culture]. Translation and Comparative Linguistics, no. 10, p. 53. 
language, reflecting the person's worldview, information about culture is reflected in the structure of the language nominations ${ }^{4}$.

In its turn, a man is a reference point in the analysis of the language phenomena; he is involved in this analysis and its ultimate goals.

A man stands at the centre of the linguistic picture of the world as the origin of all categorical coordinates of the language and as a measure of the linguistic picture of the world.

The history of the study of the man's role in language and culture is reflected in the rejection of a narrowly immanent language's perception as a kind of self-sufficient entity, a system of distinctive units; as well as in the advancement of an anthropological program for studying the language, aimed to comprehend the language in its inextricable link with human being - human consciousness, thinking, culture, a subject-practical and spiritual activity 5 .

However, the idea that the world is seen by man through the prism of his language is naturally not new. The ideas about the decisive role of the language in human thinking, the connection of language with the people's mental and spiritual life and culture belong to W. Humboldt. He considered language to be the creator of reality, shaping public consciousness. According to W. Humboldt, everything in the language is a reincarnation and reflection of the national spirit ${ }^{6}$.

The possession by person of special symbolic structures allows him to form the image (picture, model) of the world as the basis of his life. This picture of the world is many-sided and multidimensional. It unites a person's ideas about various aspects of the reality surrounding him; therefore, it is divided into religious and mythological, scientific, artistic, and other pictures of the world. The linguistic picture of the world as if refracts all symbolic structures in itself. Not copying reality, this picture creates its iconic image, interprets it. The basis for revealing the linguistic picture of the world is the study of concepts, stereotypes of the linguistic and wider cultural consciousness, which allow constructing fields with culturally significant

${ }^{4}$ Zamaletdinov R. R., Zamaletdinova G. F. (2012). Jazyk - kul'’turnyy kod natsii i klyuch k kul' 'ture vsego chelovechestva [Language - the cultural code of the nation the key to the culture of the whole humanity]. Philology and culture, vol. 2, no. 28, p. 49.

5 Katermina V. V. (2014). Rol' cheloveka v yazyke i kul'ture [Human role in language and culture]. Translation and Comparative Linguistics, no. 10, p. 54.

${ }^{6}$ Humboldt W. fon. (1985). Yazyk i filosofiya kul'tury [Language and philosophy of culture]. Moscow: Progress. 
dominants of behaviour patterns, determining the types of an ethnic and cultural community ${ }^{7}$.

It should be noted that the anthropological approach to the study of language explicitly proclaims the principle of the language comprehension in its close connection with human being. There are several approaches to the question of taking into account the language's anthropological nature and how to deploy the science of language on anthropological grounds.

The first approach (an approach to the anthropological paradigm) does not introduce a person into the theory, but considers the language itself as hypostatic, animated, mythologized, and endowed with the features of a person.

The second approach offers to consider the language as a part of a person ${ }^{8}$.

The third approach ("humanistic linguistics") proposes to consider a person (as the subject) under study in terms of the language proficiency.

The fourth approach interprets language as a person's building capability, with a person been defined as a person through language.

The latter one was given by W. Humboldt, who considered the linguistic and philosophical concept of the language to be the core of the human theory formation in the framework of philosophical and practical human science. According to W. Humboldt, the study of language does not contain a final goal, but, together with all other areas, serves the highest and common goal of the human spirit's joint aspirations?

$\mathrm{W}$. Humboldt laid the foundation of the language theory by considering it to be a result of the human spiritual power development and a human society phenomenon. The ideas of W. Humboldt created a good soil for the various concepts' emergence, with the idea been the language's elements to express a certain mental content and differences between languages to be considered as a kind of these languages speakers' peculiarities of thinking or as an embodiment of a special ethnic culture.

The will to interpret all the particular language features as its speakers' features of the thinking was further the most completely formulated in the concept of L. Weisgerber and in the hypothesis of linguistic relativity, wellknown as the Sapir-Whorf hypothesis.

${ }^{7}$ Katermina V. V. (2014). Rol' cheloveka v yazyke i kul'ture [Human role in language and culture]. Translation and Comparative Linguistics, no. 10, p. 54.

8 Al'breht E. (1967). Kritika sovremennoj lingvisticheskoj filosofii [Criticism of modern linguistic philosophy]. Moscow: Progress, pp. 80-81.

9 Katermina V. V. (2014). Rol' cheloveka v yazyke i kul'ture [Human role in language and culture]. Translation and Comparative Linguistics, no. 10, p. 53. 
Both L. Weisgerber and V. Humboldt considered language to be a mental "intermediate world", being the result of the world of things and the world of consciousness interaction. Such an interaction makes the language to create the surrounding world itself. Thus, language is an image, the world's picture, the people's worldview. The difference in languages is a manifestation of the different views on the world, so that for people speaking different languages, the world looks different ${ }^{10}$.

At the heart of each particular culture, there lies a specific model of the world that defines the person's worldview, the nature of creativity, the leading cultural paradigm, the range of moral and aesthetic imperatives for human activity. These models are the result of cultural and historical practice. The model helps to understand the uniqueness and originality of the particular culture's spiritual and material phenomena, as well as its deep inner meaning. Being engaged the live chain of information transmission between generations, a human being is most eager to find his own place within society to fulfil his human dignity ${ }^{11}$.

In its turn, human culture, social behaviour and thinking are known not to exist without and outside the language. Being a means of human communication and therefore social and national by nature, language cannot but bear the imprints of the worldview features, ethical and cultural values, as well as behavioural norms that are specific to this very language community $^{12}$.

\section{Language Identification Seen through a Prism of Ethnicity and National Character}

In the modern globalising world, with the identification process gaining strength; there are emerging such new forms of identity as: language, ethnical, professional, religious, sexual, etc. The language identity's building as a part of ethnicity and national character belonging traits is rather used by political leaders as a tool to achieve their interests. In particular, an industrial society sidelines the oral transmission of ethnic traditions, thus, broadcasting "collective narrations" in more modern ways: through educational institutions and the media. However, an ethnic group is not only an "imaginary" community, united by the idea of a common origin, but also an

${ }^{10}$ Petrova L. N. (2017). Razlichiya yazykovoy mental'nosti [Differences in language mentality]. Vestnik of Volzhsky University after V.N. Tatischev, vol. 2, no. 1, p. 60.

11 Biletska O. (2019). Multiculturalism: language and culture identity problem. Culture and Arts in the Modern World, no. 20, pp. 21-29.

${ }_{12}$ Derbisheva Z. K. Natsional'nyy mentalitet i ego otrazhenie v yazyke [National mentality and its reflection in the language]. Monumenta Altaica. Retrieved from: http://altaica.ru/Articles/mentalitet.php. 
ontologically realistically functioning group of people with certain cultural characteristics, with the language being the one of them.

Ethnicity has existed for many generations, independently preserving its distinctive features; it is a "natural" group connected by an organic form of solidarity, which is characterized by intergenerational and naturally accelerated (in nature and history) character ${ }^{13}$.

The scientific literature often uses the concepts of ethnic and national identity as synonyms. But V. Mezhuev makes a distinction between these concepts. He says that a nation, in contrast to an ethnic group is what was given to an individual not by the fact of his birth, but by his own efforts and personal choice. A person doesn't choose an ethnicity, but he chooses a nation, at least he can choose. A nation is a state, social, cultural affiliation of an individual, but not his anthropological and ethnic distinctness ${ }^{14}$. Ethnic identity is formed in the process of personality's socialization, when an individual, consciously or not, copies patterns of group behaviour, joining a certain culture through the national language, traditions, customs.

There are many nations around the world, with each of these nations creating a special culture, language, symbols, norms, morals, ways of communication and activity, artistically and sensually reproducing the world and so on. However, the most important factor, created by human, is language, being an instrument of identification, including national. The language is the basis of the universal human being in the diversity of cultures, always belonging to a certain nation ${ }^{15}$.

G. Spet, the greatest Russian philosopher, also emphasized on the language role in the formation and objectification of the nation's character and its mentality. He noted that it is possible to talk about the stability of dispositions acquired in collective experience, the constancy of the developed "internal attitudes", but these do not necessary mean "innate readiness" $" 16$. In his opinion, any historical community (people, nation, ethnic group) has the ability to independently develop a strong-willed unity, subordinating to a certain extent the individuals, it constituting. A common

13 Krasikov V. I. (1994). Chelovek na puti vstrechi s samim soboy: problema metafizicheskoy samoidentifikatsii cheloveka [A person on the path of meeting himself: the problem of metaphysical self-identification of a person]. Kemerovo: Kuzbassvuzizdat, pp. 50-51.

14 Mezhuev V. M. (1992). Ideya natsional'nogo gosudarstva v istoricheskoy perspektive [The idea of a nation-state in historical perspective]. Polis, no. 5-6, p. 14.

15 Biletska O. (2019). Multiculturalism: language and culture identity problem. Culture and Arts in the Modern World, no. 20, pp. 21-29.

${ }^{16}$ Spet G. G. (1996). Vvedenie v etnicheskuyu psihologiyu [Introduction to Ethnic Psychology]. St. Petersburg: Aleteyya, p. 190. 
language, a system of spiritual values, symbols, behaviours are passed down from generation to generation. Inherited behaviours and assessments of reality serve as models for future actions, forming relatively stable systems. They embody the cultural and historical experience of the people and reflect the uniqueness of their path. G. Speth concluded that the key to understanding the mentality of the people lies in its history, in the concrete structure of social reality, embodying the "collective spirit of the nation".

In the XX century, the study of the problems of the people's character, themental structures and forms of the cultural and historical embodiment was replaced by comprehensive studies of the national mentality and national character.

It should be emphasized that there is still no consensus among specialists regarding the essence, nature and specifics of a national character. Different researchers look at the problem of a national character and its cultural and historical significance in different ways.

L. Gumilyov believed that national character to be a myth. According to him, for each new era, the character traits of a particular ethnic group are always transformed according to the real situation, even while maintaining the sequence of ethno-genesis' phases ${ }^{17}$. Therefore, it was incorrect to consider the national character to be a stable, universal entity.

The complexity of the national character and national mentality as a subject of scientific research caused the existence of these phenomena's several dominant interpretations. The national character is referred to:

- a special mindset, expressed in a picture of the world, worldview, worldview, behavioural and motivational attitudes;

- a type of personality that is positioned as ideal, exemplary, representative for a given nation;

- psychological characteristics inherent in all representatives of a particular nation and distinguishing them from all other people;

- the set of values, ideals, beliefs that determines the lifestyle of a particular ethnic group;

- the totality of psychological traits and qualities that most representatives of a given nation have;

- typical features of behaviour and thinking that distinguish representatives of a particular nation and which are objectified in various

${ }^{17}$ Gumilev L. N. (1994). Ot Rusi do Rossii [From Russia to Russia]. Moscow: Di-Dik, p. 432. 
forms of culture $^{18}$. These interpretations reflect two types of the methodological guidelines in relation to national character: ethnicallypsychological and ethnically-cultural. The ethnically-psychological approach followers believe that the national character is a historically established set of stable mental traits of one or another ethnic group's representatives. The set of stable mental traits determines the usual manner of behaviour and the typical course of a certain ethnic group representatives' action and is manifested in their attitude to the social and domestic environment, to the world around, to other ethnic communities. The most important thing in this concept is that the national character is determined not through the qualities and properties of a particular individual, but through the qualities and properties attributed to an entire ethnic community, having its own culture (symbols, customs, and traditions) ${ }^{19}$. In its turn, the ethnically psychological approach to understanding the national character has been repeatedly criticized in the works of the American sociologist P. Sorokin. The properties of social and cultural communities cannot be reduced to the qualities of their constituent individuals: an individual's behaviour and the nation's nature as a whole are not identical. P. Sorokin emphasized that the cultural characteristics of an individual are not inherited biologically, but are acquired through various interactions with people, he is born among, brought up, and educated. In the process of cultural interactions, a person masters the specific character traits of his national group. Examples are known when a representative of one ethnic group finds himself at an early age in another country and grows up, forms in a different ethnic and cultural environment: subsequently he considers himself in language, thoughts, and manner of behaviour to be a representative of this particular ethnic and cultural environment ${ }^{20}$.

The relationship of personality and nation is a separate case of the dialectics of the single and the general, the individual and the gens. A person, of course, has the features that characterize the nation as a whole. To one degree or another and in one way or another, these specific national

${ }^{18}$ Kuznetsova E. V. (2011). Samoopredelenie naroda: natsional'nyy mentalitet [Selfdetermination of the people: national mentality]. Vestnik of Lobachevsky State University of Nizhni Novgorod. Series: Social Sciences, vol. 2, no. 22, p. 83.

${ }^{19}$ Ibid.

${ }^{20}$ Sorokin P. (2000). Sotsial'naya i kul'turnaya dinamika: issledovaniya izmeneniy v bol'shikh sistemakh iskusstva, istiny, etiki, prava i obshchestvennykh otnosheniy [Social and Cultural Dynamics: Studies of Change in Large Systems of Art, Truth, Ethics, Law and Social Relations]. St. Petersburg: Russskaya Khristianskaya Gumanitarnaya Akademiya, pp. 463-489. 
character traits are present in a significant number of individuals who make up a given commonality, a given nation ${ }^{21}$.

E. Fromm tried to comprehend the dynamic nature of a national character, its connection with the characteristics of social and cultural being. Through the disclosure of the social potential of a national character, he explained many social transformations taking place within society. Exploring the dynamic nature of a national character, the scientist believed that character can be defined as a system of aspirations that underlie behaviour, but are not identical to the behaviour itself. Thus, the national character can be considered as a set of aspirations, desires, motives, intrinsically inherent to most ethnophores, corresponding to ethnical and national norms and values, aimed at adapting to external conditions with the aim of self-preservation ${ }^{22}$.

However, the national character cannot be reduced only to modes of behaviour; it is a complex, systemic mechanism for the adaptation of a nation to certain natural and social conditions of its existence.

Summing up, we may say that the characteristic features of the language identification as a form of national identity are determined by the characteristics of the ethnic subject. From this point of view, language selfconsciousness is characterized by: stability and long-term existence, binary (contrasting "we - they"), the presence of basic cultural values, traditionalism, and syncretism.

\section{The Language Policy of Ukraine and the Issue of National Identification}

The current situation builds up new models of identity, with its specifics being a person to feel himself as "his" for the world and "other" for his close environment. In a state of total uncertainty, practices of identification are becoming increasingly important. As in modernism the problem of identity was how to create and preserve it as a stable and strong one, so in postmodernism the issue of identity transformed itself and focused on how to avoid the identity fixation and to preserve freedom ${ }^{23}$.

In conditions when a number of the international communication subjects has significantly increased, it is difficult to preserve one's language and

${ }^{21}$ Kuznetsova E. V. (2011). Samoopredelenie naroda: natsional'nyy mentalitet [Selfdetermination of the people: national mentality]. Vestnik of Lobachevsky State University of Nizhni Novgorod. Series: Social Sciences, vol. 2, no. 22, p. 83.

22 Fromm E. (1989). Begstvo ot svobody [Escape from freedom]. Moscow: Progress, p. 178.

${ }^{23}$ Biletska O. (2019). Multiculturalism: language and culture identity problem. Culture and Arts in the Modern World, no. 20, pp. 21-29. 
culture. A modern Ukrainian researcher L. Zabolotska says that the question of the language role in forming the state as well as preserving it has acquired a special sound in the context of the modern language situation at the edge of XX-XXI centuries ${ }^{24,25}$.

In this context, the problem of the personality identification is one of the most significant within modern civilization processes. This issue has repeatedly been covered by scientists, philosophers, psychologists and other researchers. Of particular interest is the study of national identification ${ }^{26}$, covering such areas as social and cultural self-identification, linguistic identification, because each type of identification intersects with another. Thus, language is an important factor both in human self-identification and in national identification. It is a unique phenomenon, a human culture's integral part and its expression ${ }^{27}$.

National identification involves the interdependence of the subjective and objective, spiritual and moral, civic consciousness and self-identification of each individual representative of society, collective thought and personal sense of patriotism, language identification, as well as social and cultural self-identification, since only the interaction of these factors may bring the country to progress, prosperity and global recognition. This stage forms the national identity, thus showing the public aspirations' integrity, been tangible in the organization of power, that ensures the preservation of the society traditions, internal order forms, individual freedoms ${ }^{28}$.

In the process of national identification, the linguistic identification of each individual plays an important role, because it becomes the factor of social consolidation and the motive power of building a strong, democratic and independent state. Language becomes an instrument by which society can protect its own interests, history, and traditions. The national language deficiency is one of the most serious obstacles to be overcome when

${ }^{24}$ Kostyria Y. (2019). Language and culture in the European integration strategy of Ukraine. International Relations: Theory and Practical Aspects, no. 4, pp. 176-186.

25 Zabolotska L. (2012). Ukrainska mova v konteksti suchasnoi movnoi sytuatsii Ukrainy (do pytannya pro yii rol $\mathrm{v}$ umovakh hlobalyzatsii) [Ukrainian language in the context of the current language situation of Ukraine (on the question of its role in the context of globalization)]. Almanac of Ukrainian Studies, no. 9, p. 347.

${ }^{26}$ Dzhozef Dzh. (2005). Yazyk i natsional'naya identichnost' [Language and national identity]. Logos, vol. 4, no. 49, pp. 4-32.

27 Rusanivskyi, V. M. (2004). Movna kartyna svitu v etnokulturnii paradyhmi [Linguistic picture of the world in the ethnocultural paradigm]. Movoznavstvo, no. 4, p. 3 [in Ukrainian].

28 Potello N., Nerukh N. (2005). Pro movnu identyfikatsiiu u suspilnomu seredovyshchi Ukrainy [On language identification in the public environment of Ukraine]. Ukrainian Studies, no. 4, pp. 286-288. 
building a national identity ${ }^{29,30}$.Thus, language refers to the state's attributes; it is one of the determining factors of the people's state system altogether with borders, territory, army, taxes. Therefore, the question of the state language's position is of the same significance as the state's national security question ${ }^{31}$.Emerged as an independent state in 1991, Ukraine is a multi-constituent state entity with different historical and socially cultural regional traditions. The historical path, modern Ukraine regions have gone through, determines a diverse language situation in the state. That is why the variegated language situation, the population's multi-ethnicity, and various historical symbols of the Ukrainian regions required a careful humanitarian policy, including in the field of the language use.

Since the early 1990s humanitarian issues were focused on the national culture revival. From the Ukrainian ruling leadership's point of view only the Ukrainian language should be to be the state language, it should be used for the administration, training and work of state authorities. A part of the nationally oriented elites and a proportion of the population considered the Ukrainian language to be a pillar of statehood and identity. This thought was expressed in the slogan: "The Single language - the single state". The implementation of this slogan was the adoption of the Constitution of Ukraine, in which, according to article 10, the state language of Ukraine is the Ukrainian language ${ }^{32}$. Throughout the 1990s state bodies of Ukraine carried out the policy of "Ukrainization", i.e. the development of Ukrainian education in the regions with the Russian language being dominant, moving office work into the Ukrainian language, etc. The lack of state status of the Russian language in a country where the majority of the population fluently spoke Russian and $42 \%$ considered it native, led to the formation of social movements and political parties, aiming to give the Russian language the status of a second state. The strongest resistance to the policy of "Ukrainization" was in regions with an absolute predominance of the Russian language - the Crimea, Donetsk and Luhansk regions.

The language issue escalated during the 2004 Presidential elections with two leading candidates: V. Yanukovych was for the Russian language

${ }^{29}$ Dzhozef Dzh. (2005). Yazyk i natsional'naya identichnost' [Language and national identity]. Logos, vol. 4, no. 49, pp. 4-32.

30 Salohubova O. Ye. (2009). Mova v svitohliadnykh oriientatsiiakh ukraintsiv [Language in the worldviews of Ukrainians]. Humanitarian Bulletin of Zaporozhye State Engineering Academy, no. 38, pp. 52-59.

31 Udovenko G. I. (2005). Yazykovaya politika Ukrainy na sovremennom etape [Language policy of Ukraine at the present stage]. Golos Ukrainy, no. 206, pp. 8-9.

32 Verkhovna Rada of Ukraine. (2019). Konstytutsiia Ukrainy [Constitution of Ukraine] Law from June 28, 1996, № 254k/96-VR. Kyiv: Alerta. 
gaining the status of the state language, and V. Yushchenko was the opponent. The distribution of electoral support of V. Yushchenko and V. Yanukovych among the regions of Ukraine coincided with the language prevalence within the regions. So, the Russian-speaking Southeast supported V. Yanukovych, while the mostly Ukrainian-speaking West and the Centre of the country supported V. Yushchenko (Pic. 1).

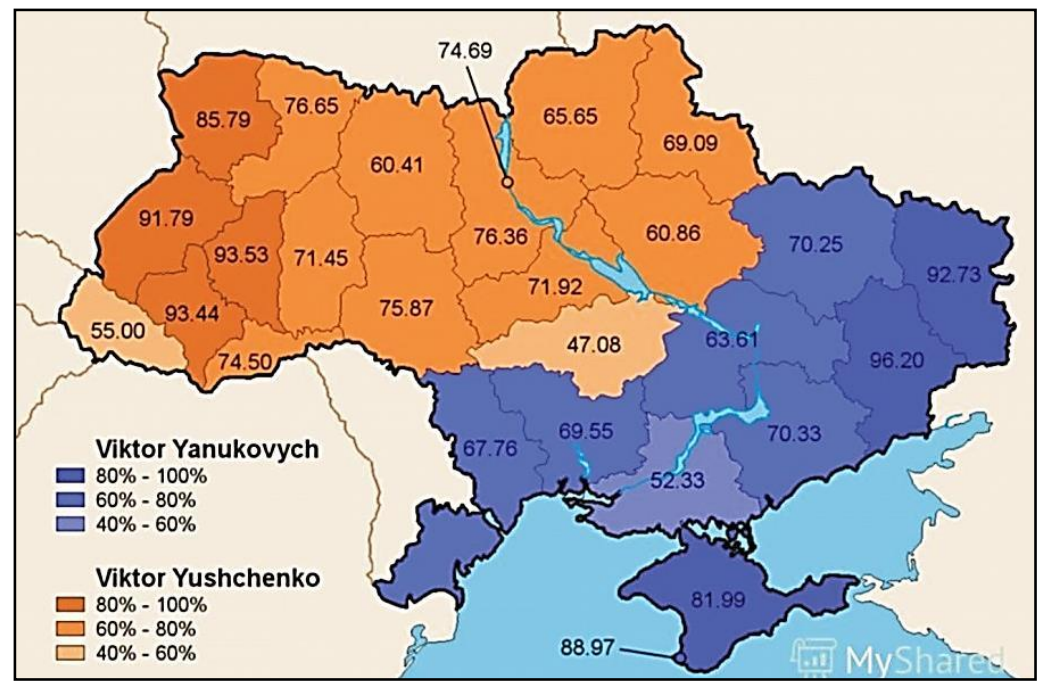

\section{Distribution of voters by region (\%) Presidential Election in Ukraine, $2004^{33}$}

The period after the "Orange Revolution" was marked by the strengthening of the "Ukrainization" policy, namely the implementation of the humanitarian policy.

In 2010 the election of V. Yanukovych as president led to the language policy turnaround. The key milestone of his presidency was the adoption of the Law of Ukraine "On the Basics of State Language Policy" No. 5029-VI, in 2012. According to the adopted Law, the so-called regional languages were introduced in Ukraine. These are languages that, according to the census, more than $10 \%$ of the corresponding region population considered to be native. Within such a region, the regional language can be used in legislatively established areas along with the state Ukrainian language. The

${ }^{33}$ Distribution of voters by region. Retrieved from: Distribution of voters by region. 
decision to use the language is made by the regional authorities. The Law on Regional Languages gave the opportunity for municipal and regional administrations to independently decide on the use of the language, taking into account the local specifics. As a result, the Russian-speaking regions of the Southeast used the opportunity to give the Russian language the status of the state. At the same time, Halychchyna, Volyn and a number of other territories could preserve the monopoly of the Ukrainian language in the field of public administration and the education system.

Since 2014, the new ruling political elite of Ukraine set integration into Euro-Atlantic structures as a strategic goal and took a number of measures to restrict the use of Russian and some other languages in the media, education system and other areas.

On September 6, 2017, the Verkhovna Rada adopted the Law of Ukraine "On Education" No. 2145-VIII ${ }^{34}$, according to which the language of the general educational process is the state language. Schoolchildren belonging to national minorities are guaranteed the right to study in the language of a national minority. To ensure this right, separate classes and groups will be created, while higher education will be carried out in Ukrainian.

At the end of May 2017, the Verkhovna Rada introduced the Draft Law on the introduction of amendments to the laws of Ukraine, including the need for audio (electronic) communications No. 2054-VIII, dated 23.05.2017. The draft law establishes that for television and radio organizations of the national broadcasting category, the share of broadcasts and / or films in Ukrainian should be at least $75 \%$ during the day in each time interval from 7.00 to 18.00 and from 18.00 to 22.00 . For television organizations of regional and local speech categories, the Law establishes an obligatory share of the Ukrainian-language content at the level of $50 \%$. In other words, the draft law "On the State Language" involves expanding the use of the Ukrainian language "as a tool for uniting Ukrainian society, a means of strengthening state unity and territorial integrity of Ukraine, its independent statehood and national security". It provides that the Ukrainian language as the state language will be used in government and in all other public spheres of public life. The law does not apply only to private communication and worship: they can still be held in Russian, Polish, Latin or other languages. The Ukrainian language should be used in the educational sector and in labour relations, in medical institutions, in customer service and advertising. Newspapers and magazines may be

${ }^{34}$ Verkhovna Rada of Ukraine. (2017). Zakon Ukrainy "Pro osvitu” [Law of Ukraine “About education”] from September 5, 2017, № 2145-VIII. Retrieved from: https://zakon.rada.gov.ua/cgi-bin/laws/main.cgi?Nreg=2145-19. 
published in other languages, but they must also have Ukrainian-language versions. In libraries, bookstores and newsstands, at least $50 \%$ of the products must be in the official language.

On July 16, 2019, the Law "On ensuring the functioning of the Ukrainian language as the state language $" 35$ entered into force in Ukraine.

But the current situation of the Ukrainian language in Ukraine does not correspond to either the ethnic composition or the linguistic orientations of the population. So, according to the 2001 census, the Ukrainians make up $76 \%$, and the Russians $17 \%$. Ukrainian is considered to be the native language by $67.5 \%$ of the population of Ukraine, which is 2.8 percent more than according to the 1989 census. $29.6 \%$ of the population was identified Russian as the native language (compared to the previous census, this indicator decreased by 3.2 percent). $85.2 \%$ of the Ukrainians consider the Ukrainian language to be the one of their nationality, and only $14.8 \%$ consider Russian the same ${ }^{36}$.

Thus, analysing the current state of Ukrainian society and the functioning of language policy at the present stage, we can distinguish the following main characteristics as: Ukrainian-Russian bilingualism and diglossia; coexistence in a single Ukrainian space of three regions (West, South and East, Centre and North) with different national-cultural, socio-political traditions and - as a result - mutually political orientations, linguistic and speech priorities and habits; the formal nature of the language policy in the state, the lack of real social status of the Ukrainian language ${ }^{37}$.

But the language issue today still remains the subject of political debate and most often acts as an element of speculation both by political forces and representatives of civil society. In current situation the formation of Ukraine as an independent state depends not only on its economic situation, but also on the position of the state language in it. The state should be interested in the

${ }^{35}$ Verkhovna Rada of Ukraine. (2017). Proekt Zakonu Ukrainy "Pro zabezpechennia funktsionuvannia ukrainskoi movy yak derzhavnoi" [Draft of the Law of Ukraine On ensuring the functioning of the Ukrainian language as the state language] from June 9, 2017, № 5670-d. Retrieved from: http://search.ligazakon.ua/1_doc2.nsf/link1/ JH4DI7LV.html

36 Gosudarstvennyy komitet statistiki Ukrainy. (2001). Chislennost' $i$ sostav naseleniya Ukrainy po itogam Vseukrainskoy perepisi naseleniya 2001 goda [The number and composition of the population of Ukraine according to the results of the 2001 AllUkrainian Population Census]. Retrieved from: http://2001.ukrcensus.gov.ua/rus/ results/general/nationality/

37 Zabolotska L. (2012). Ukrainska mova v konteksti suchasnoi movnoi sytuatsii Ukrainy (do pytannya pro yii rol $\mathrm{v}$ umovakh hlobalyzatsii) [Ukrainian language in the context of the current language situation of Ukraine (on the question of its role in the context of globalization)]. Almanac of Ukrainian Studies, no. 9, p. 348. 
dominant position of the Ukrainian language. It is obliged to generate, maintain and disseminate the Ukrainian language environment. The Ukrainian language in the state process of Ukraine should be assigned a leading role - a full-fledged language of the nation and state. Finally, to fulfil its main task of consolidating the Ukrainian - ethnic and political - nation.

\section{CONCLUSIONS}

Specificity of linguistic identity formation is determined by the tendencies of development of modern society: globalization processes, return to authenticity, emphasis on identity, as well as tendencies in modern social and humanitarian cognition, connected with peculiarities of the social reality. There are some common trends, such as the problems of time and space and the experience of transcribing meanings. Indeed, the latter question has gained popularity due to the fact that the experience of radical change is accompanied by a widespread sense of inability to modify the usual order of things. Moreover, in social reality, a variety of variants of coding of social experience emerges, as the ability to differentiate between realities is improved. In addition, human life is increasingly shifting from the natural world to the realm of meanings and meanings.

A linguistic personality as a native speaker of a particular language stores in its consciousness information in linguistic units, rules and norms of use. As a carrier of a particular language and culture, a linguistic personality is a national type.

It is the presence of linguistic and cultural identity as a factor of national identity, most fully manifested in the social expressiveness of the individual, ethnicity as a whole part of the people, mitigates rigid and inevitable globalization tendencies, which convincingly confirm that the revival of ethnic self-conscious conditions assimilation. After all, the human does not exist outside the nation, which, by involving man in humanity, accumulates his experience in his specific practice. Therefore, there is every reason to argue that the universal is within the nation, within that socio-cultural activity that can be of universal importance without losing its national identification. And it prevents this loss, first and foremost, of the language, the linguistic consciousness of the people, which, being a form of selfexpression of the people, of their civilization expression, by the very factor of their existence, undoubtedly proves that with all the strengthening of the global interdependence of the human community, the world was, is and will be multifaceted, the planet (as in previous times) will remain inextricably linked to the concepts of national culture and clear national landmarks in all walks of life. This position is completely in line with the realities of the 
Ukrainian ethnic group, which has a great history, which defines it as a specifically Ukrainian self-portrait of humanity with its individual culture.

\section{SUMMARY}

The current globalized world faces a number of challenges. The very problem of national identity is of a particular acuity, as it is the closely relates the processes of self-awareness and the modern individual's ideological orientations. Particular attention draws the issue of the language importance as an important means of the individual's self-determination as well as the national identity-building tool in the context of post-totalitarian society transformations. At the heart of each particular culture, there lies a specific model of the world that defines the person's worldview, the nature of creativity, the leading cultural paradigm, the range of moral and aesthetic imperatives for human activity. There are many nations around the world, with each of these nations creating a special culture, language, symbols, norms, morals, ways of communication and activity, artistically and sensually reproducing the world and so on. However, the most important factor, created by human, is language, being an instrument of identification, including national. The language is the basis of the universal human being in the diversity of cultures, always belonging to a certain nation. Thus, language is an important factor both in human self-identification and in national identification. It is a unique phenomenon, a human culture's integral part and its expression.

\section{REFERENCES}

1. Al'breht E. (1967). Kritika sovremennoj lingvisticheskoj filosofii [Criticism of modern linguistic philosophy]. Moscow: Progress. (in Russian)

2. Biletska O. (2019). Multiculturalism: language and culture identity problem. Culture and Arts in the Modern World, no. 20, pp. 21-29.

3. Derbisheva Z. K. (n.d.). Natsional'nyy mentalitet i ego otrazhenie v yazyke [National mentality and its reflection in the language]. Monumenta Altaica. Retrieved from: http://altaica.ru/Articles/mentalitet.php (accessed 15 November 2020).

4. Dzhozef Dzh. (2005). Yazyk i natsional'naya identichnost' [Language and national identity]. Logos, vol. 4, no. 49, pp. 4-32.

5. Fromm E. (1989). Begstvo ot svobody [Escape from freedom]. Moscow: Progress. (in Russian)

6. Gosudarstvennyy komitet statistiki Ukrainy. (2001). Chislennost' $i$ sostav naseleniya Ukrainy po itogam Vseukrainskoy perepisi naseleniya 2001 goda [The number and composition of the population of Ukraine according to the results of the 2001 All-Ukrainian Population Census]. 
Retrieved from: http://2001.ukrcensus.gov.ua/rus/results/general/nationality/ (accessed 15 November 2020).

7. Gumilev L. N. (1994). Ot Rusi do Rossii [From Russia to Russia]. Moscow: Di-Dik. (in Russian)

8. Humboldt W. fon. (1985). Yazyk i filosofiya kul'tury [Language and philosophy of culture]. Moscow: Progress. (in Russian)

9. Katermina V. V. (2014). Rol' cheloveka v yazyke i kul'ture [Human role in language and culture]. Translation and Comparative Linguistics, no. 10 , pp. 52-54.

10. Kostyria Y. (2019). Language and culture in the European integration strategy of Ukraine. International Relations: Theory and Practical Aspects, no. 4, pp. 176-186.

11. Krasikov V. I. (1994). Chelovek na puti vstrechi s samim soboy: problema metafizicheskoy samoidentifikatsii cheloveka [A person on the path of meeting himself: the problem of metaphysical self-identification of a person]. Kemerovo: Kuzbassvuzizdat. (in Russian)

12. Kuznetsova E. V. (2011). Samoopredelenie naroda: natsional'nyy mentalitet [Self-determination of the people: national mentality]. Vestnik of Lobachevsky State University of Nizhni Novgorod. Series: Social Sciences, vol. 2, no. 22, pp. 80-85.

13. Maslova V. A. (2001). Lingvokul'turologiya [Linguoculturology]. Moscow: Akademiya. (in Russian)

14. Mezhuev V. M. (1992). Ideya natsional'nogo gosudarstva v istoricheskoy perspektive [The idea of a nation-state in historical perspective]. Polis, no. 5-6, pp. 10-15.

15. Petrova L. N. (2017). Razlichiya yazykovoy mental'nosti [Differences in language mentality]. Vestnik of Volzhsky University after V.N. Tatischev, vol. 2, no. 1, pp. 59-65.

16. Potebnya A. A. (1999). Mysl' $i$ yazyk [Thought and language]. Moscow: Labirint. (in Russian)

17. Potello N., Nerukh N. (2005). Pro movnu identyfikatsiiu u suspilnomu seredovyshchi Ukrainy [On language identification in the public environment of Ukraine]. Ukrainian Studies, no. 4, pp. 286-288.

18. Rusanivskyi, V. M. (2004). Movna kartyna svitu v etnokulturnii paradyhmi [Linguistic picture of the world in the ethnocultural paradigm]. Movoznavstvo, no. 4, pp. 3-7.

19. Salohubova O. Ye. (2009). Mova v svitohliadnykh oriientatsiiakh ukraintsiv [Language in the worldviews of Ukrainians]. Humanitarian Bulletin of Zaporozhye State Engineering Academy, no. 38, pp. 52-59.

20. Sorokin P. (2000). Sotsial'naya $i$ kul'turnaya dinamika: issledovaniya izmeneniy $v$ bol'shikh sistemakh iskusstva, istiny, etiki, prava $i$ 
obshchestvennykh otnosheniy [Social and Cultural Dynamics: Studies of Change in Large Systems of Art, Truth, Ethics, Law and Social Relations]. St. Petersburg: Russkaya Khristianskaya Gumanitarnaya Akademiya. (in Russian)

21. Spet G. G. (1996). Vvedenie v etnicheskuyu psihologiyu [Introduction to Ethnic Psychology]. St. Petersburg: Aleteyya. (in Russian)

22. Udovenko G. I. (2005). Yazykovaya politika Ukrainy na sovremennom etape [Language policy of Ukraine at the present stage]. Golos Ukrainy, no. 206, pp. 8-9.Verkhovna Rada of Ukraine. (2017). Proekt Zakonu Ukrainy "Pro zabezpechennia funktsionuvannia ukrainskoi movy yak derzhavnoi" [Draft of the Law of Ukraine On ensuring the functioning of the Ukrainian language as the state language] from June 9, 2017, № 5670-d. Retrieved from: http://search.ligazakon.ua/1_doc2.nsf/link1/JH4DI7LV.html_ (accessed 15 November 2020).

24. Verkhovna Rada of Ukraine. (2017). Zakon Ukrainy "Pro osvitu"[Law of Ukraine "About education"] from September 5, 2017, № 2145-VIII. Retrieved from: https://zakon.rada.gov.ua/cgibin/laws/main.cgi?Nreg=2145-19 (accessed 15 November 2020).

25. Verkhovna Rada of Ukraine. (2019). Konstytutsiia Ukrainy [Constitution of Ukraine] Law from June 28, 1996, № 254k/96-VR. Kyiv: Alerta. (in Ukrainian)

26. Zabolotska L. (2012). Ukrainska mova v konteksti suchasnoi movnoi sytuatsii Ukrainy (do pytannya pro yii rol $\mathrm{v}$ umovakh hlobalyzatsii) [Ukrainian language in the context of the current language situation of Ukraine (on the question of its role in the context of globalization)]. Almanac of Ukrainian Studies, no. 9, pp. 347-350.

27. Zamaletdinov R. R., Zamaletdinova G. F. (2012). Jazyk - kul'’turnyy kod natsii i klyuch $\mathrm{k}$ kul'ture vsego chelovechestva [Language - the cultural code of the nation the key to the culture of the whole humanity]. Philology and culture, vol. 2, no. 28, pp. 49-53.

\section{Information about the author: Biletska Oksana orcid.org/0000-0003-1785-9607} Candidate of Cultural Studies, Associate Professor Kyiv National university of Culture and Arts 36, Ye. Konovaltsia St., Kyiv, 01133, Ukraine 